Article

\title{
The Public Health Impact of Road-Traffic Noise in a Highly-Populated City, Republic of Korea: Annoyance and Sleep Disturbance
}

\author{
Taeho Park ${ }^{1}$, Minho Kim ${ }^{2}$, Chaemi Jang ${ }^{1}$, Taeryang Choung ${ }^{3}$, Kyung-A Sim ${ }^{4}$, Dongju Seo ${ }^{5}$ \\ and Seo Il Chang $1, *$ (1) \\ 1 Department of Environmental Engineering, University of Seoul, Seoul 02504, Korea; \\ dreamer2442@uos.ac.kr (T.P.); jcm1125@uos.ac.kr (C.J.) \\ 2 School of Space and Environment Studies, Sangmyung University, Seoul 03061, Korea; mhkim@smu.ac.kr \\ 3 NVT Co. Ltd., Seoul 04597, Korea; trchoung@gmail.com \\ 4 Gwangju Metropolitan City Office, Gwangju 61945, Korea; kashim@korea.kr \\ 5 Public Health \& Environment Research Institute of Gwangju, Gwangju 61976, Korea; eastwine83@korea.kr \\ * Correspondence: schang@uos.ac.kr; Tel.: +82-2-6490-2865
}

Received: 18 July 2018; Accepted: 15 August 2018; Published: 20 August 2018

check for updates

\begin{abstract}
Sustainable transportation is an essential part of a sustainable city; however, modern transportation systems with internal-combustion engines emits unacceptably high level of air-pollutants and noise. It is recognized widely that road-traffic noise has negative health impacts (such as annoyance and sleep disturbance) on exposed population in highly-populated cities. These harmful effects should be removed or at least reduced to guarantee the sustainability of modern cities. The estimation of pollutant levels at a specific location and the extent of the damage is therefore important for policy makers. This study presents a procedure to determine the levels of road-traffic noise at both day and night, and an assessment of the adverse health effects across Gwangju Metropolitan City (GMC), Republic of Korea (ROK). Road-traffic noise maps in 2-D and 3 -D were generated, in order to find spatial distribution of noise levels across the city and noise level at the façade of a building-floor, respectively. The adoption of existing assessment models for the highly-annoyed (\%HA) and highly-sleep-disturbed (\%HSD) leads to building-based estimation of the affected population and spatial distribution of the road networks of the city. Very high noise levels were found to exist along major roads in the day and at night, with little difference between them. As a result, approximately $10 \%$ and $5 \%$ of the total population $(n=1,471,944)$ were estimated to experience high-level annoyance and sleep disturbance, respectively.
\end{abstract}

Keywords: road-traffic noise; negative health impacts; annoyance; sleep disturbance; 3-D noise map

\section{Introduction}

Environmental noise, also known as community noise, is undesirable sound that is emitted from various sources, including transportation, industries, construction sites, and neighborhoods. The World Health Organization (WHO) has recognized it as a harmful pollutant that has ill impacts on public health [1]. Taking environmental noise into account, the European Union (EU) has adopted the Environmental Noise Directive (END) that focuses on assessing population exposed to community noise, reducing harmful noise levels, and mitigating its burden of adverse public health [2-5].

Based on the recent END revision [6], noise pollution continues to be a major environmental problem in Europe with the following consequent set of health effects backed by sufficient evidence: annoyance [7], sleep disturbance with awakenings [8,9], hypertension ischemic heart disease [10-12], mental health [13], and even learning impairment [14-16]. 
Annoyance and sleep disturbance are known to be the most important psychological impacts of community noise [17-20]. Annoyance is a human feeling of displeasure that typically includes anger, disappointment, anxiety and depression [21,22]. Nighttime noise causes interrupted sleep of residents in a community, and disturbed sleep could lead to fatigue, depression, and decreased performance, among others $[21,23,24]$.

In this context, since the END's prescription for noise maps and action plans, the scientific community has made many efforts-from high-level studies to proposed mitigation systems-to curb for the following sources of noise in urban areas: road-traffic [25,26], railway traffic [27,28], airport [29,30], and industrial [31,32]. In addition, country areas (outside urban borders) have a new noise source-wind turbines-that are large in number and have been studied to be highly annoying [33,34].

Transportation is a major source of community noise, particularly in modern urban environments of many nations, where dense traffic systems are well developed [22,35-39]. Road traffic is known to play a dominant role in environmental noise and affects more people than other forms of transportation $[18,40,41]$. For instance, approximately 100 million people are estimated to be exposed to harmful levels-above 55 decibels (dB)—of road traffic noise in Europe [42]. Road traffic noise has been found to have a strong association with annoyance and directly caused awakening and alterations of sleep stages, particularly at night $[21,22,43-48]$.

Perceiving transportation noise as an environmental problem, the Republic of Korea (ROK), which is an emerging country in Asia, recently amended the Noise and Vibration Regulation Act of 1990 to produce road traffic noise maps for highly-populated urban areas. Some studies using the maps pointed out that the road traffic noise levels of ROK were higher than those of EU member states and many people were exposed to very high noise levels $[49,50]$. However, the researches offer limited reporting on the number of people exposed to road-traffic noise levels, and the ill-impacts of road traffic noise on health.

This research aims at providing an overview of the health impacts of road traffic noise in a densely-populated metropolitan city of the ROK, focusing on annoyance and sleep disturbance. In addition, we present spatial distribution of the estimated population across the city that is psychologically affected as a result.

\section{Material}

\subsection{Study Area}

Gwangju Metropolitan City (GMC), selected as the study area in this research, is a highly populous urbanized region in the southwestern part of the ROK territory. Based on the 2015 nationwide census [51], GMC has approximately 0.6 million households, where 1.5 million people lived. The population density of the city (2998 person $/ \mathrm{km}^{2}$ ) was the third highest among metropolitan cities in the nation although its area $\left(501 \mathrm{~km}^{2}\right)$ was the smallest compared to the others. In 2015, 0.6 million vehicles were registered with the city's government, and the percentage of their types was as following [52]: passenger cars $(81.1 \%)$, heavy vehicles $(14.6 \%)$, and vans/special vehicles $(4.3 \%)$. Due to the location of a car manufacturing complex, heavy vehicles like trucks, not registered in the city, frequently run along some routes of the city area.

The GMC consists of five sub-level (-i.e., -gu-level) districts for an administrative purpose, as indicated in Figure 1. Each gu-level district consists of several dong-level divisions and the city currently consists of 202 dongs in total. Dong-gu is recognized as an old town, where the City Hall was located. The city hall was recently relocated to Seo-gu, a new town area in the city. This research also presents the spatial distribution of land use and land cover (LULC), recently generated by the ROK Ministry of Environment (ME), in Figure 1. As illustrated in the figure, the urban development of the city was made in a circular pattern, and residential area covers around $16 \%$ of the city's total area. 
The percentage of individual residential types is as follows: $63 \%$ for high-rise apartment buildings, $31 \%$ for low-rise detached houses, and $6 \%$ for others such as row houses and multiplex house.

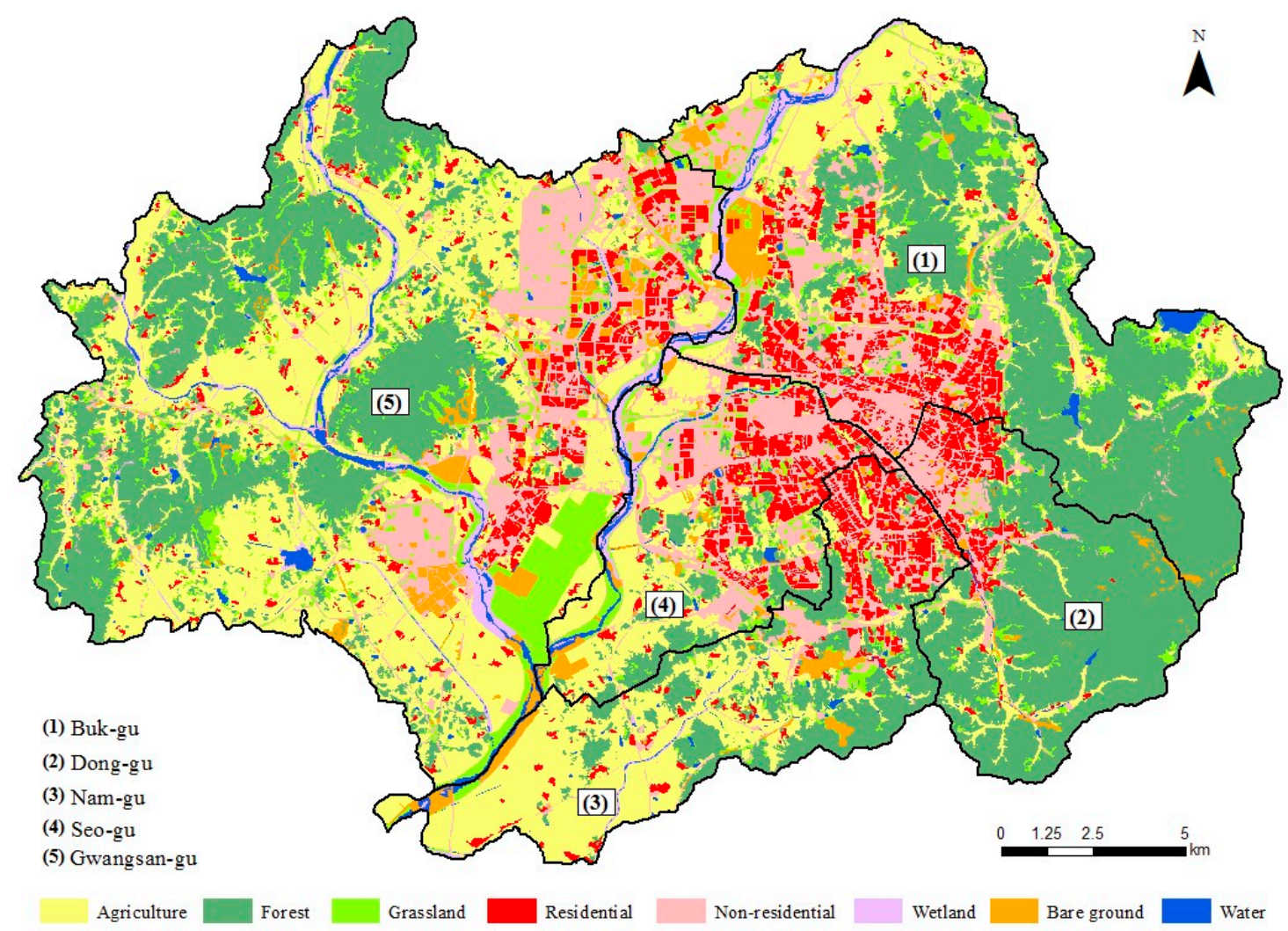

Figure 1. Land use and land cover of Gwangju Metropolitan City.

\subsection{Input Data}

The levels of road traffic noise can be measured at given locations by a field survey with a sound-level meter. However, it captures short-term results of the noise levels and distinguishing road traffic transportation from other noise sources in the measured data is difficult. Noise mapping, as another method, provides long-term average sound levels that are emitted from a target source like road traffic transportation. Therefore, we adopted this approach to assess the health impacts of road traffic noise, focusing on annoyance and sleep disturbance.

In general, noise mapping is performed with a sound propagation model that requires a variety of data, such as building, topography, road network, traffic volume, vehicle types and speed $[2,53,54]$. Table 1 summarizes input data that were utilized in generating the road traffic noise maps of the study area. Topography and building footprints were primary data to develop a 3-D urban model that is described in Section 2.3. LiDAR is a remote sensing technique that utilizes laser pulse and acquires point data set with the heights of artificial features above terrain surface [55]. We utilized LiDAR data from 2007, since there was no recent data set for the GMC. Besides the data sets, we included noise barriers, also known as protection wall, for noise mapping, because they could influence the propagation of traffic noises emitted from individual roads. In addition, we obtained population statistics of 2015 Census to estimate the number of residents in individual buildings; this is documented in Section 2.4. 
Table 1. Summary of input data used for road traffic noise map generation.

\begin{tabular}{|c|c|c|c|c|}
\hline Type & Parameter & Provider & Production Year & $\begin{array}{c}\text { Access } \\
\text { Constraints }\end{array}$ \\
\hline $\begin{array}{c}\text { Topography } \\
\text { LiDAR }\end{array}$ & $\begin{array}{l}\text { Terrain elevation } \\
\text { Noise barrier } \\
\text { Point could }\end{array}$ & $\begin{array}{l}\text { National } \\
\text { Geographic } \\
\text { Information } \\
\text { Institute }\end{array}$ & $\begin{array}{l}2016 \\
2007\end{array}$ & Public Proprietary \\
\hline Road & Network & & 2016 & Proprietary \\
\hline Vehicle & $\begin{array}{l}\text { Volume } \\
\text { Speed } \\
\text { Type }\end{array}$ & $\begin{array}{c}\text { Gwangju } \\
\text { Metropolitan } \\
\text { Police Agency }\end{array}$ & 2016 & Proprietary \\
\hline Building & $\begin{array}{l}\text { Footprint } \\
\text { Elevation }\end{array}$ & $\begin{array}{c}\text { Gwangju } \\
\text { Metropolitan City } \\
\text { Office }\end{array}$ & 2016 & Public \\
\hline Sound-proof tunnel & Footprint & & & Proprietary \\
\hline
\end{tabular}

The total length of roads was reported to be $1,832 \mathrm{~km}$ in 2015; spatial distribution of the road network is shown in Figure 2. In the figure, most tunnels marked in cyan color were developed beneath mountains. A beltway, called the 2nd Ring Road, passes around residential areas of the city. In addition, a highway called the Honam Expressway, runs through two districts of Buk-gu and Gwangsan-gu. The speed limits of the two roads are higher than those of the others.

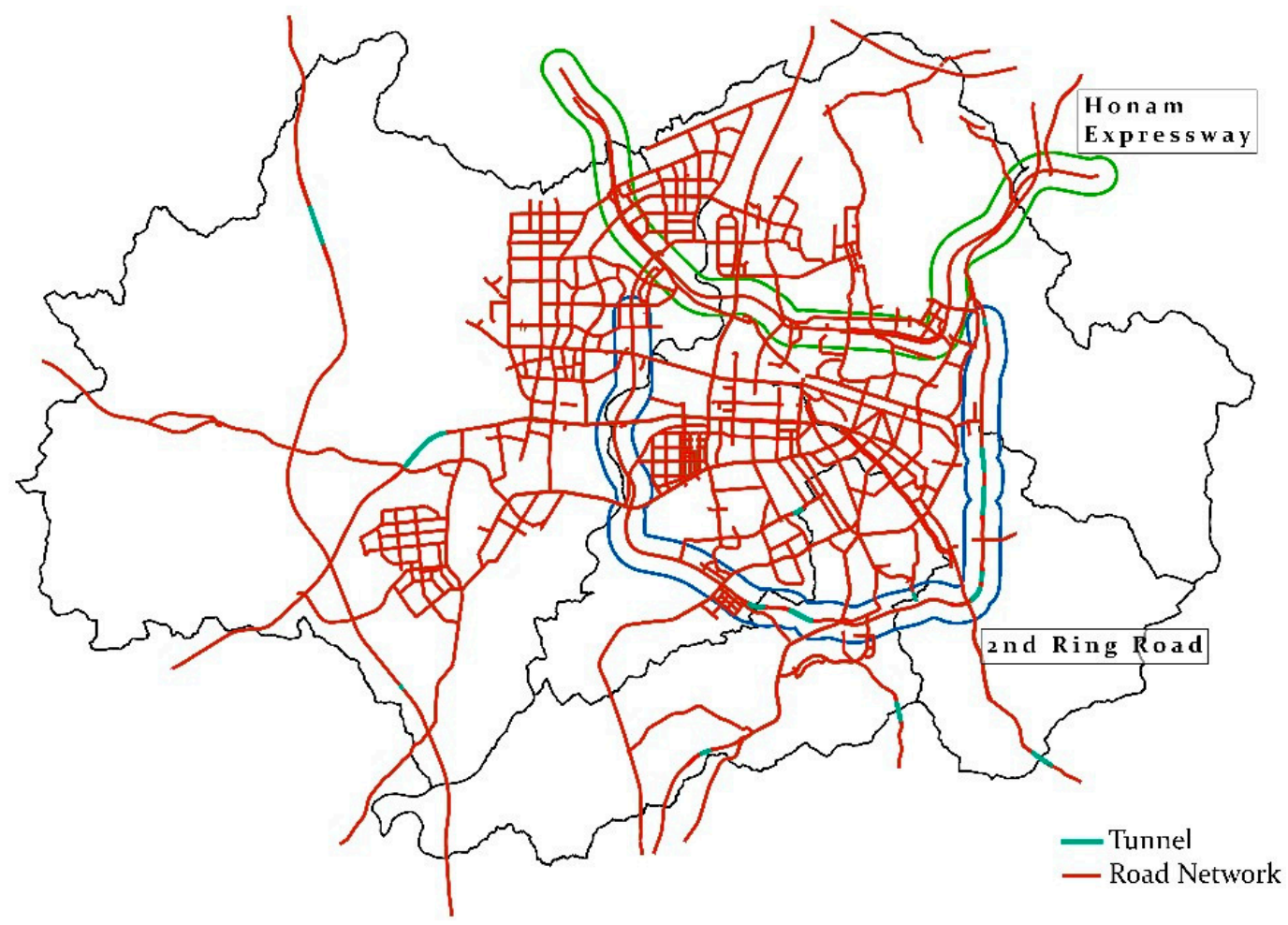

Figure 2. Road network of Gwangju Metropolitan City.

Figure 3 provides the geographic distribution of 131,078 buildings in 3-D (based on the number of floors). Over half of the buildings were found to be located in Gwangsan-gu and Buk-gu with percentages of $26.6 \%$ and $25.0 \%$, respectively. Nam-gu followed them with $19.3 \%$, and the other two districts had around $14.5 \%$ of the total number of buildings. 


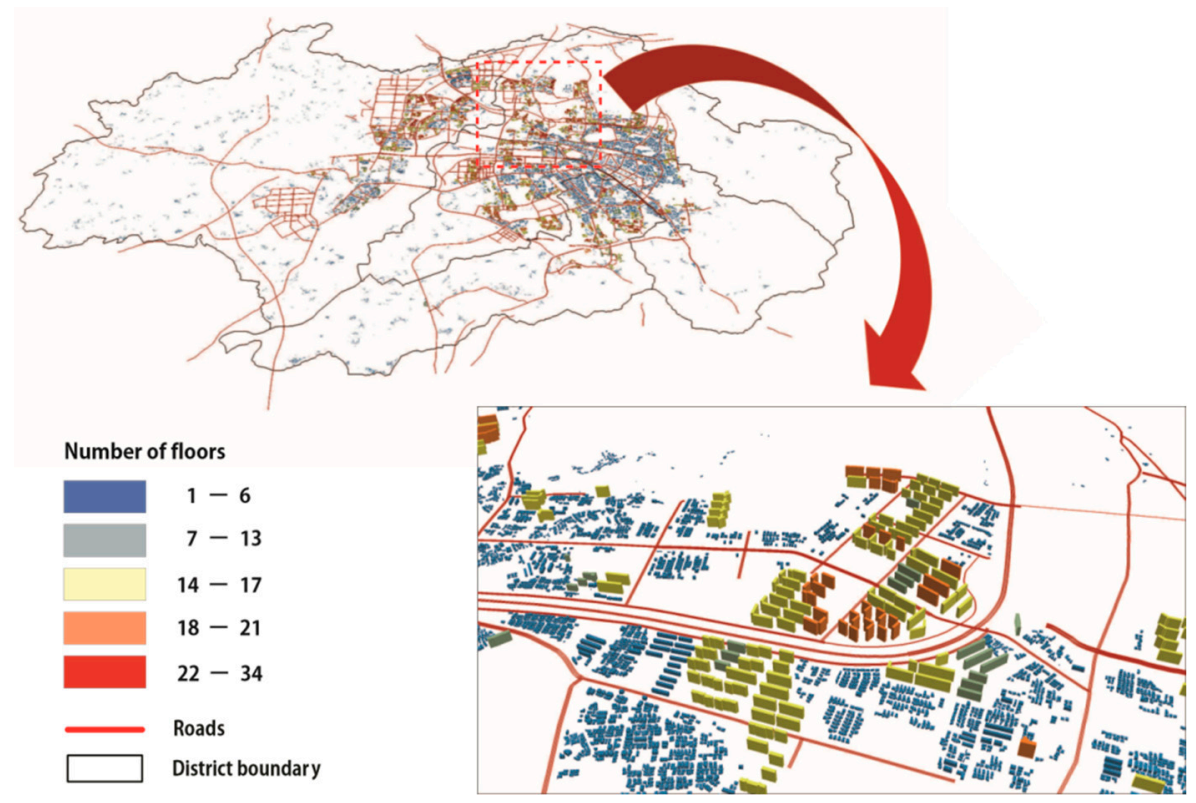

Figure 3. Presentation of individual buildings based on the number of floors.

\subsection{Road Traffic Noise Mapping}

The noise mapping of road traffic transportation is generally subdivided into two phases, i.e., developing a 3-D urban model and applying a selected sound propagation model. In the first phase, developing such an urban model is important because traffic noises are reflected and diffracted when they propagate across a given city area $[38,56]$. In general, we need elevations and heights of terrain surfaces and artificial features such as buildings, roads, and noise barriers for this purpose [57].

The 3-D urban model of the GMC was generated by SoundPLAN ${ }^{\mathrm{TM}}$ (version 7.4) [58]. The software internally calculates terrain elevation based on triangulated irregular network; contour lines extracted from topography data are entered into the computation. The heights of individual buildings are also required for producing the urban model; footprint data of buildings, however, contained only the number of floors without heights. Therefore, we utilized LiDAR points for determination of building heights. Meanwhile, since the data set was acquired in 2007, there was no information on recently-developed buildings. After our research and acquiring of new data, we applied the ROK ME noise mapping guideline, called the Notice 2016-117 Noise Mapping Method. The Notice recommends we multiply the number of floors by a scale factor as following: $2.8 \mathrm{~m}, 2.9 \mathrm{~m}$, and $3.1 \mathrm{~m}$ for a detached house, an apartment building, and a commercial building, respectively.

In 3-D urban modeling, the SoundPLAN ${ }^{\mathrm{TM}}$ also needs the elevation values of individual surfaces and overpass roads. Since surface roads are constructed right above the Earth's surface, their elevations can be obtained directly from those of terrain surfaces. On the other hand, we used LiDAR data to compute the elevations of individual overpass roads. A total of 456 noise protection walls were detected in topography data, but no height information was available. Therefore, we conducted a field survey to acquire the geometric attributes of each barrier, such as shape, length, and height. All the data sets were then entered into the noise-mapping software for developing a 3-D urban model of the GMC.

For noise mapping over a wide area such as the GMC, the ME of ROK recommends RLS90 [59], NMPB [60], CRTN [61], ASJ 2003 [62] and Nord 2000 [63] as road traffic noise models. In the second phase, we produced 2-D noise maps for both day and night (hereafter called grid noise maps) and a 3-D one (hereafter called facade noise map), based on the RLS90 implemented in SoundPLAN ${ }^{\mathrm{TM}}$. Daytime and nighttime grid noise maps were generated at a sound level of $L_{e q}$ with a size of $10 \mathrm{~m}$ at $1.5 \mathrm{~m}$ above the terrain surface. We studied the two grid maps to gain insights on spatial distribution of 
road traffic noise levels across the GMC, at both day and night. For the facade noise map, the receiver points were placed at $1 \mathrm{~m}$ apart in the center of the building facade plane. The ROK ME requires 3-reflection order, and $5000 \mathrm{~m}$ for noise source searching radius. The ground absorption of urban area was considered to be perfectly reflective.

The RLS90 model was tested by comparing predicted levels with measured levels, as shown in Figure 4 . The noise levels were measured at a total of 604 points, including 456 points at $1.5 \mathrm{~m}$ above the terrain surface and 148 points at the facade of high-rise apartment buildings. We measured noise level at each point for one hour and also collected traffic volume, speed and vehicle type. The assessment result of noise prediction accuracy is presented in Figure 4. It was discovered that the differences between predicted and measured noise levels were within $\pm 3 \mathrm{~dB}(\mathrm{~A})$.

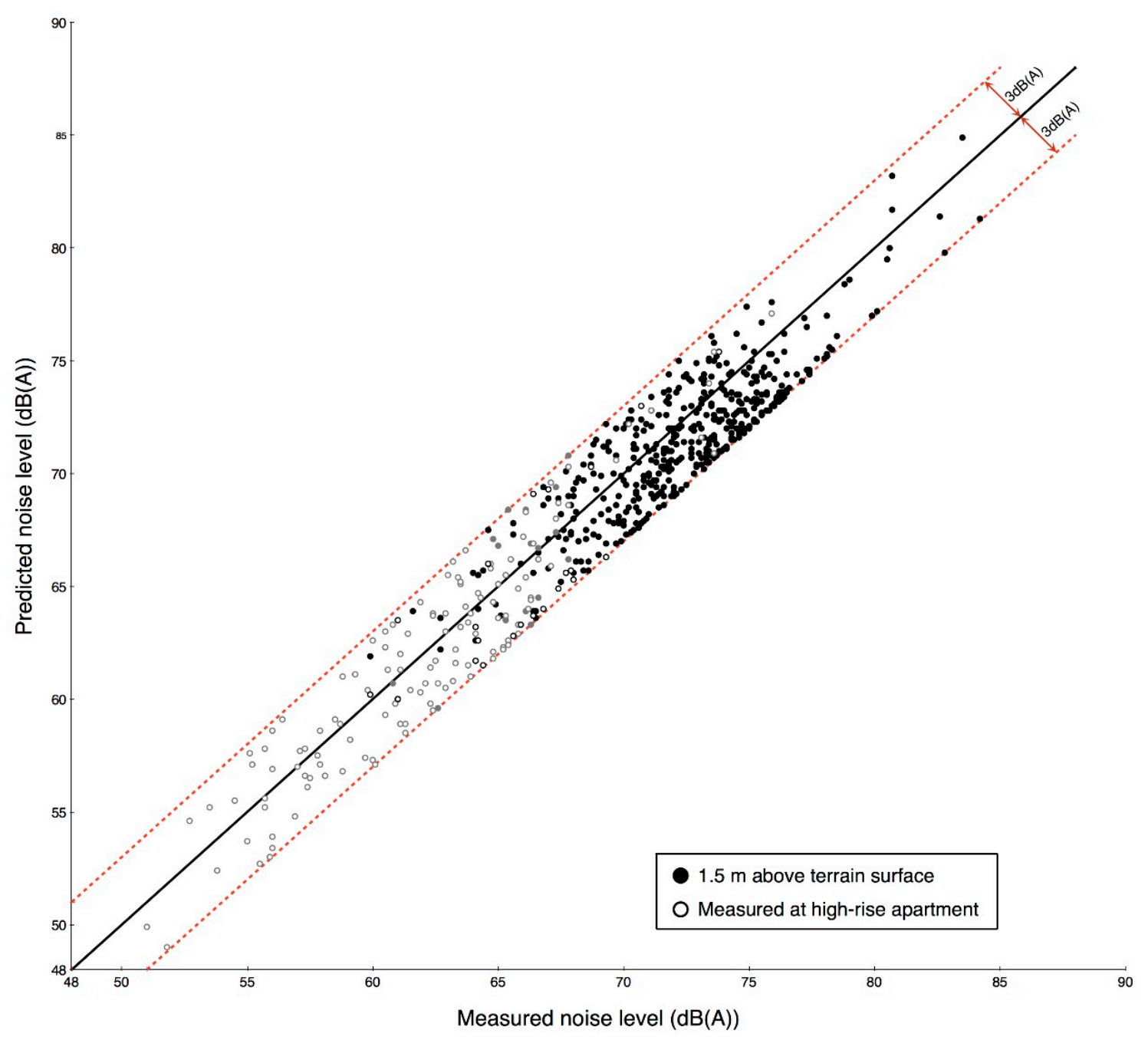

Figure 4. Comparison between predicted and measured noise levels.

This research adopted the levels of road traffic noise received at each facade of every floor for a building in assessing the psychological impacts of human exposure. Such a noise map was known to result in more accurate estimates of human exposure in the ROK [50]. To do so, we produced a facade noise map with day-night noise level, i.e., $L_{D N}$, using the following equation:

$$
L_{D N}=10 \log \left(\frac{15}{24} \times 10^{\frac{L_{D}}{10}}+\frac{9}{24} \times 10^{\frac{L_{N}+10}{10}}\right),
$$

where $L_{D}$ and $L_{N}$ stands for daytime and nighttime noise levels, respectively. 


\subsection{Estimation of Building Population and Human Exposure Analysis}

Human exposure analysis needs the population statistics of each building to estimate the number of people exposed to road traffic noise levels. However, there were no available building-based population data in the ROK, so we followed the general practice of the European Commission to estimate the population of each residential building [3].

This analysis follows a series of the estimations of the population per unit floor area of a building in a sub-district administrative unit ( $k_{t h}$ dong), $\alpha_{k}$, the population of each floor for the building, $P_{j k}$, and the number of people on each facade of a target building, $P_{i j k}$, expressed as follows:

$$
\alpha_{k}=\frac{P_{k}}{\sum_{j}\left(A_{j k} \times N F_{j k}\right)},
$$

where $P_{k}, A_{j k}$, and $N F_{j k}$ represent population of $k_{t h}$ dong-level district, a total area of floors for $j_{t h}$ building in the district, and the number of floors for building $j$ of the district, respectively. The number of people per floor of the building, $P_{j k}$, can be obtained from:

$$
P_{j k}=\alpha_{k} \times A_{j k}
$$

The population of $i_{t h}$ facade plane on $j_{t h}$ building in a $k_{t h}$ dong-level district, $P_{i j k}$, can be obtained from:

$$
P_{i j k}=P_{j k} \times \frac{L_{i j k}}{\sum_{i} L_{i j k}},
$$

where $L_{i j k}$ stands for the width of $i_{t h}$ facade plane.

Annoyance and sleep disturbance are known as the most adverse health outcomes of transportation noise, and they were found to affect over 8 million European adults $[7,19,64-70]$. Taking these statistics into account, this research performed human exposure analysis of road traffic noise, focusing on health outcomes, with the day-night noise levels and population estimates of each facade for individual buildings across the GMC. In doing so, we employed the percentages of highly-annoyed people (\%HA) and highly sleep-disturbed people (\%HSD) that were developed by Miedema and Oudshoorn [7] and Miedema et al. [64]. The computational equations of the two measures are as following:

$$
\begin{gathered}
\% \mathrm{HA}=9.994 \times 10^{-4}\left(L_{D N}-42\right)^{3}-1.523 \times 10^{-2}\left(L_{D N}-42\right)^{2}+0.538\left(L_{D N}-42\right) \\
\% \mathrm{HSD}=20.8-1.05 L_{N}+0.01486 L^{2}{ }_{N}
\end{gathered}
$$

where $L_{D N}$ and $L_{N}$ indicate day-night and nighttime levels of road traffic noise, respectively.

We multiplied \%HA and \%HSD to $P_{i j k}$, the predicted population of each facade for individual floors to derive the total number of people at risk of being highly-annoyed and highly sleep-disturbed, respectively. The facade-based estimates of the two measures were summed to obtain the human exposure results of each building in order to assess the psychological health impacts of road traffic noise at both city and district levels.

The per-building population estimates for annoyance and sleep disturbance were then utilized in Getis-Ord Gi* analysis, implemented in Esri ArcGIS (version 10.1), to identify hot and cold spots. The analysis is used to detect statistically significant spatial clusters of high values (i.e., hot spots) and low values (i.e., cold spots) [71], based on computed z-scores of individual units. Therefore, the hot and cold spots provide an insight into the geographic clusters of high- and low-level \%HA and \%HSD populations, respectively. 


\section{Results}

Figure 5 shows the grid maps of road traffic noise levels, predicted at $1.5 \mathrm{~m}$ above terrain surface, for daytime and nighttime. No considerable differences were found in the spatial pattern of road traffic noise levels between day and night. As illustrated in the figure, high level of noise largely occurred along highways and arterial roads, and the highest noise levels were observed near the ring roads of the GMC and the Honam Expressway passing through the north of the city. On the contrary, lower-level noises appeared at places that were close to tunnels or where sound-proof tunnels were located.
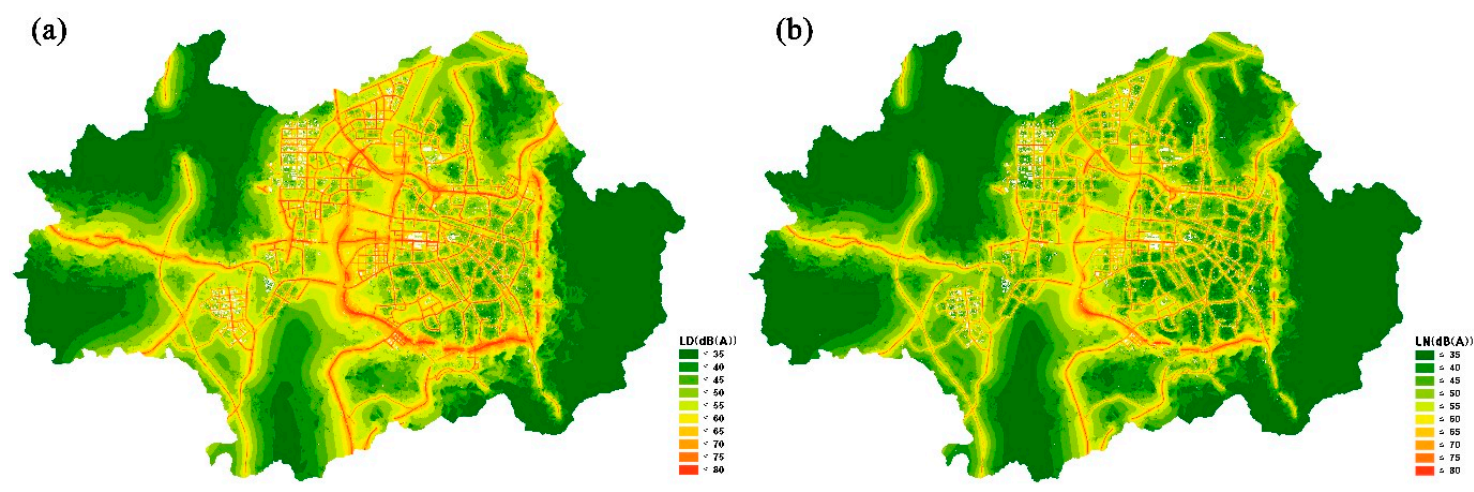

Figure 5. Road traffic noise maps of Gwangju Metropolitan City: (a) daytime and (b) nighttime.

Figure 6 shows the areas and the populations of the GMC exposed to daytime and nighttime road traffic noise. In the figure, the noise levels of $23.9 \%$ of GMC area exceed $55 \mathrm{~dB}(\mathrm{~A})$, the daytime recommended level by WHO [1] and $34.7 \%$ of population are exposed to the exceeded levels. In addition, $\mathrm{WHO}$ recommends $45 \mathrm{~dB}(\mathrm{~A})$ for nighttime and the corresponding rates for the exceeded area and population of GMC were $46.8 \%$ and $71.3 \%$, respectively.
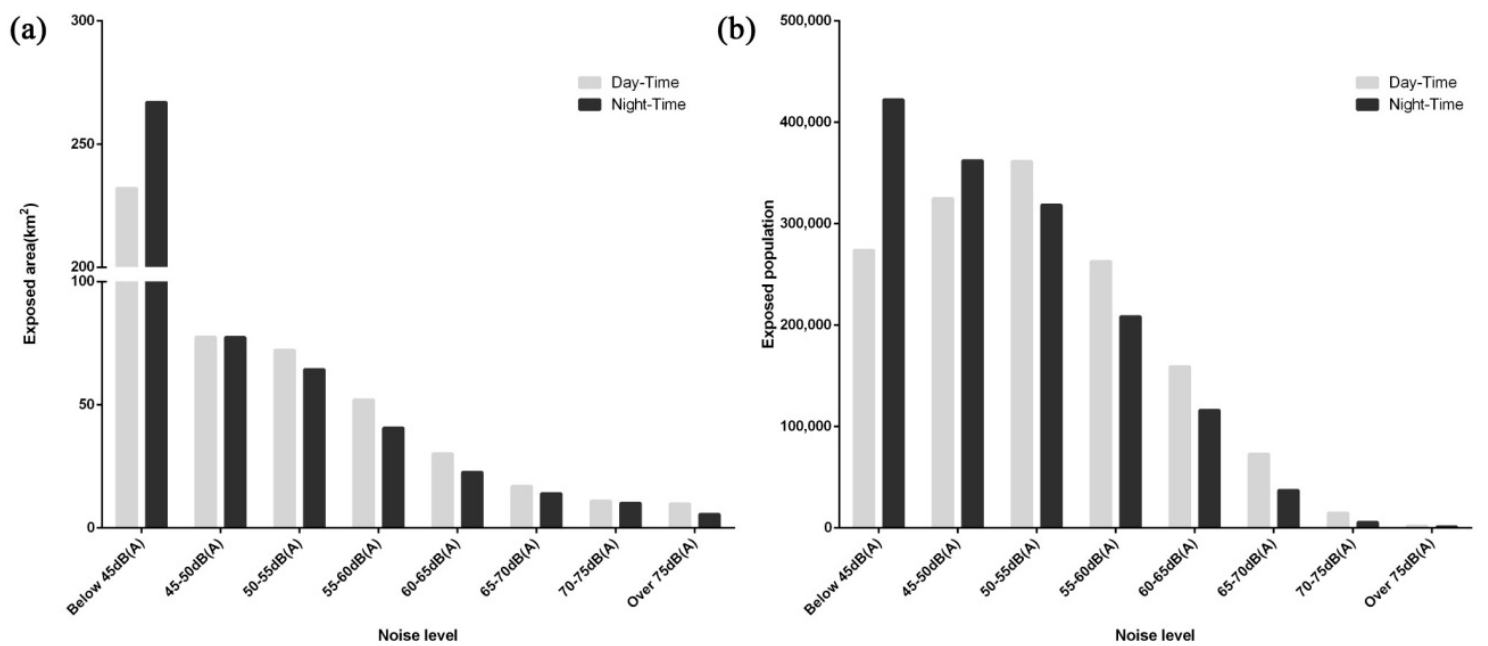

Figure 6. (a) Exposed area and (b) exposed population for daytime and nighttime.

The health impacts of road traffic noise need to be assessed with facade noise maps, instead of grid maps, considering noise propagation in a real-world human settlement environment. Therefore, this research adopted facade maps with day-night and nighttime noise levels to calculate \%HA and $\%$ HSD, respectively. Figure 7 illustrates facade noise maps for a portion of the study area. 


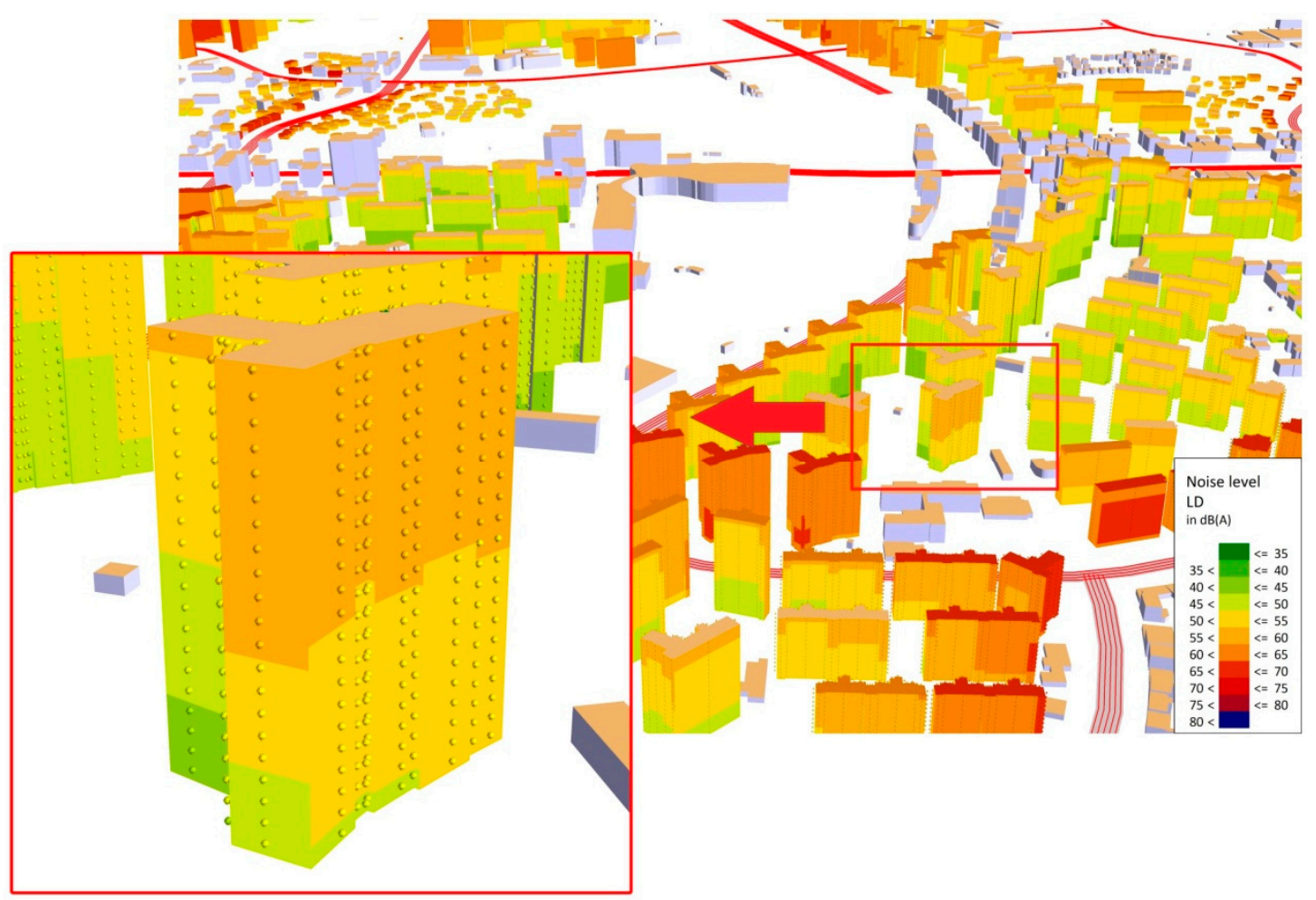

Figure 7. Facade noise map for a residential area with high-rise apartment buildings.

This research predicted the population estimates of each facade for individual floors of buildings, as described in Section 2.4. The total number of people per building was then derived by summing all facades estimates, as shown in Figure 8. Individual polygons were extruded with their predicted populations for a presentation purpose. In Figure 8, the tall buildings are apartment houses with a larger number of people than blue-colored detached houses.

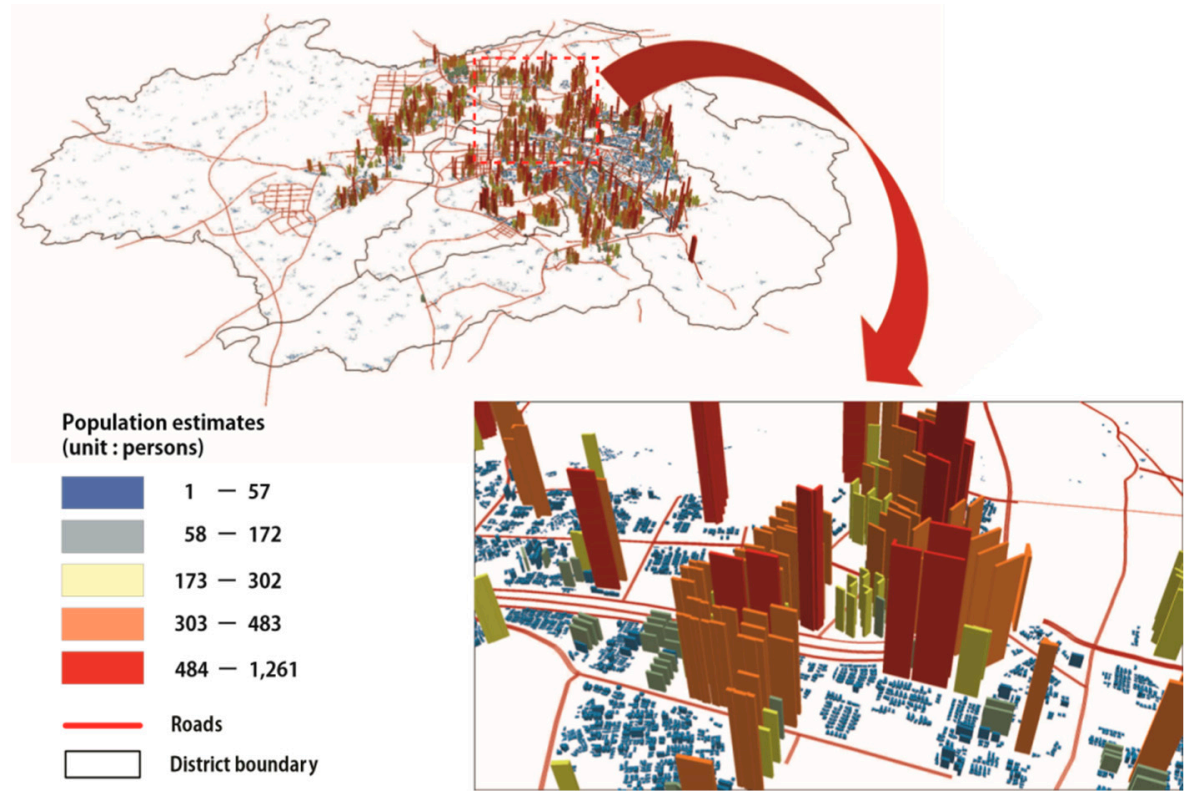

Figure 8. Estimated population of each building across Gwangju Metropolitan City. 
This research estimated the facade-level population of \%HA and \%HSD and summed them for each building. Figure 9 shows the extrusions of individual buildings based on estimates of the two health measures; the same class intervals were adopted for a comparison purpose. Although not clearly visible in Figure 9, there was a similar spatial pattern between \%HA and \%HSD predictions. That is, it was discovered that the larger numbers of both measures occurred near the 2nd Ring Road and the Honam Expressway.
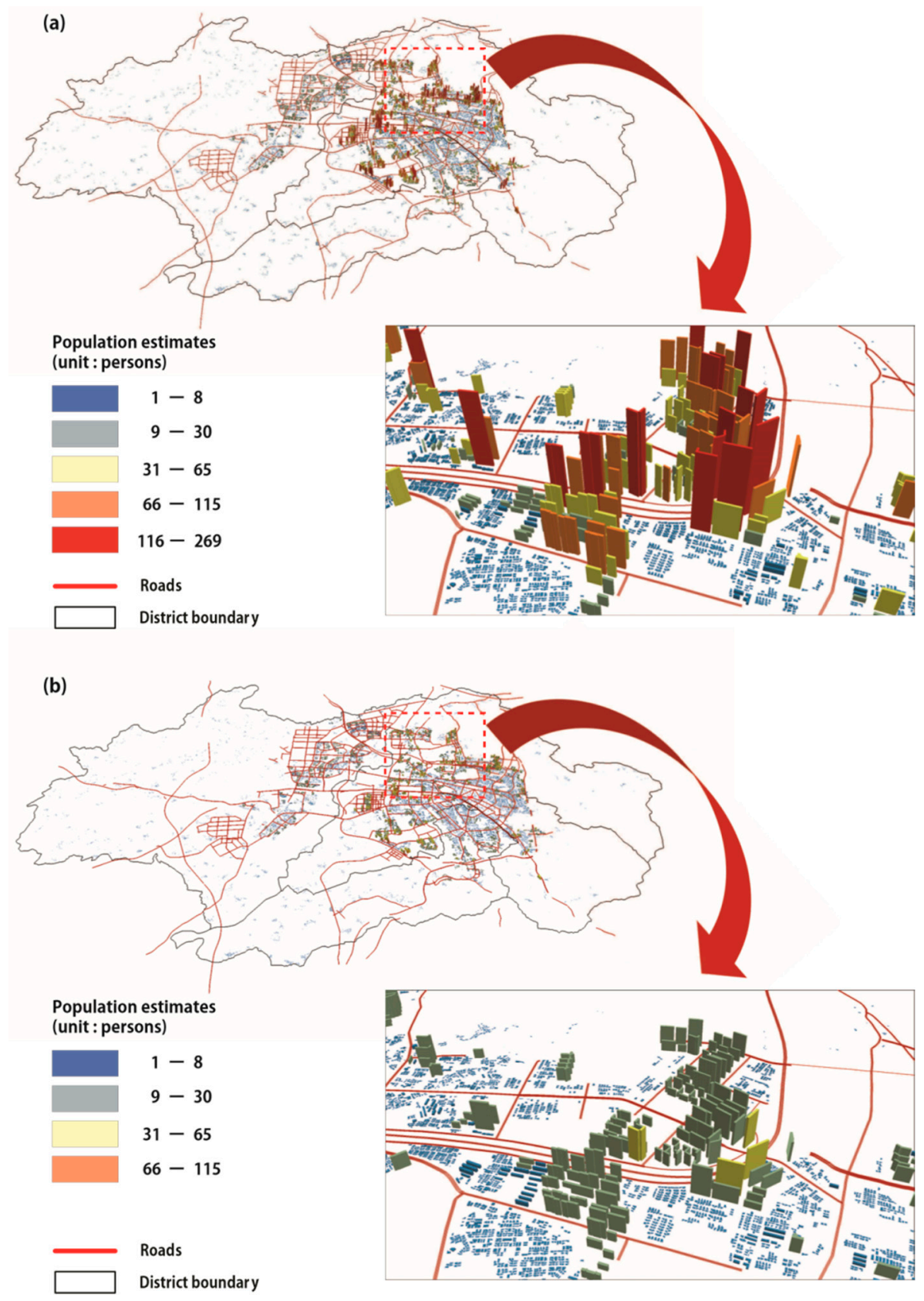

Figure 9. Population estimates of individual buildings with negative health effects of road traffic noise: (a) annoyance and (b) sleep disturbance.

Besides the visual presentation, we computed the prevalences of \%HA and \%HSD at both city and district levels and present them in Table 2. The prevalence stands for the percentage of the impacted population against the total population at both city and district levels. As summarized in Table 2, annoyance was found to be negatively impacting the residents of the GMC more than sleep 
disturbance, which can be also be seen from visual interpretation of per-building \%HA and \%HSD predictions in Figure 9.

Table 2. The impact of road traffic noise with high-level annoyance and sleep disturbance for individual gu-level districts.

\begin{tabular}{cccccc}
\hline & \multirow{2}{*}{$\begin{array}{c}\text { Total } \\
\text { District }\end{array}$} & \multicolumn{2}{c}{ High Annoyance } & \multicolumn{2}{c}{ High Sleep Disturbance } \\
\cline { 3 - 6 } & Population & $\begin{array}{c}\text { Population } \\
\text { Affected }\end{array}$ & Prevalence (\%) & $\begin{array}{c}\text { Population } \\
\text { Affected }\end{array}$ & Prevalence (\%) \\
\hline Gwangsan-gu & 399,254 & 16,912 & 4.2 & 12,704 & 3.2 \\
Nam-gu & 221,409 & 10,766 & 4.9 & 7608 & 3.4 \\
Dong-gu & 99,044 & 9196 & 9.3 & 4902 & 4.9 \\
Buk-gu & 446,737 & 57,853 & 13.0 & 27,951 & 6.3 \\
Seo-gu & 305,500 & 46,361 & 15.2 & 21,315 & 7.0 \\
Total & $1,471,944$ & 141,088 & 9.6 & 74,480 & 5.1 \\
\hline
\end{tabular}

Such tendency was also detected at the district level, but there were some differences. The most obvious impact of annoyance appeared in Dong-gu, Seo-gu, and Buk-gu where its prevalence was around two times as high as sleep disturbance. On the other hand, no considerable distinctions were noticed in Nam-gu and Gwangsan-gu. In the GMC, Seo-gu and Buk-gu were found to have the most ill-health effects of road traffic noise, based on their prevalences of \%HA and \%HSD. On the contrary, Nam-gu and Gwangsan-gu were considered to have better acoustic environment than the other districts.

Figure 10 depicts the geographic distributions of hot- and cold-spot buildings, derived from the Getis-Ord $\mathrm{Gi}^{*}$ analysis with \%HA and \%HSD sums for each spatial unit, i.e., individual buildings. In the figure, the hot and cold spots of annoyance and sleep disturbance were significant at $p<0.01$ $(99 \% \mathrm{CI})$, which had $\mathrm{z}$-scores greater than +2.58 and less than -2.58 , respectively. We observed that a similar distribution pattern for hot spots occurred between annoyance and sleep disturbance. The hot-spot buildings were generally located inside the 2nd Ring Road and near both the road and the Honam Expressway. It was assumed to occur possibly due to the following reasons: (1) high-level road traffic noise emitted from the two roads with heavy traffic volume and high vehicle speeds and (2) large number of residents in high-rise apartment buildings. The population and residential types could also influence cold-spot buildings for \%HA and \%HSD surrounded by the beltway and the highway. Most of them were low-rise detached homes with a relatively small number of residents. When the resources for mitigation measures are limited, priority should be determined on the basis of not only on noise levels, but also the impacted population and the building-based hot- and cold-spot analysis in Figure 10; it can be a very useful tool for policy makers. From Figures 5 and 10, it is found that the large clustered cold-spot area in Figure 10 still has a high level of noise, but its impacted population is relatively low; thus, priority should be given to the hot-spot area. Although the area and population exceeding a standard can be obtained from Figure 6, they are usually based on an administrative unit.

As mentioned above for Table 2, annoyance was supposed to be more severe than sleep disturbance, based on the total number of the affected population, estimated at the district level. However, although the statistics is not provided here, the hot- and cold-spot analysis in Figure 10 showed that the road traffic noise of the GMC had a more adverse effect on sleep disturbance than annoyance. 

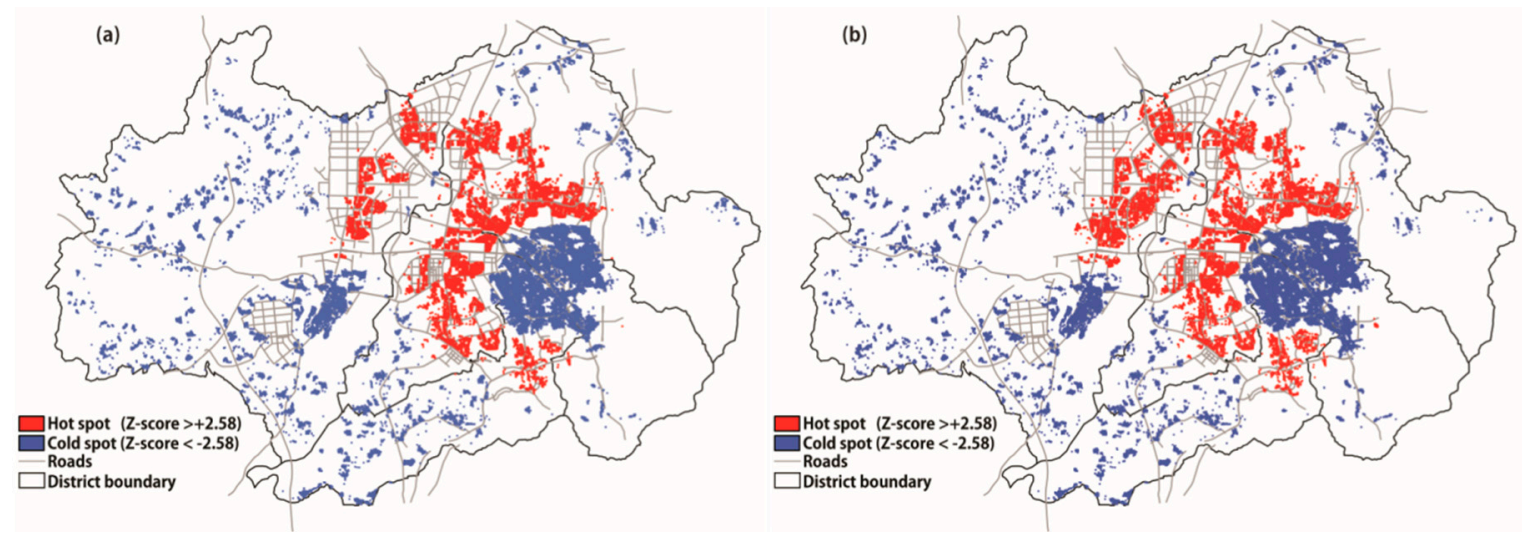

Figure 10. Geographic distributions of hot- and cold-spot buildings: (a) annoyance and (b) sleep disturbance.

\section{Discussion}

This research assessed the overall negative health impacts of road traffic noise at a building level in a highly urbanized area, i.e., GMC, of the ROK. Based on comparisons of previous literature, there is a noticeable health impact of road traffic noise in the highly-populated city, particularly at night. For instance, Kim et al. [66] estimated that $9.5 \%$ and $2.3 \%$ of the total population in Fulton County of Georgia, United States, had high levels of annoyance and sleep disturbance, respectively. The \%HSD prevalence of the GMC was over two times as high as that of the county, although there was a similar level of \%HA prevalence in the two urbanized areas. Such difference in noise impact could result partially from high levels of nighttime road traffic noise, as presented in Figure 5.

In addition, urban form influences the higher levels of sleep disturbance in the GMC with densely-located high-rise residential buildings near major roads such as beltways and highways. The characteristics of urban form is known to affect different patterns of nighttime human exposure between Eastern and Western cities [18,72]. This is also partially confirmed by another study for an Asian city. Brown et al. [73] predicted the prevalence of \%HSD in Hong Kong to be $4.1 \%$ of 10,077 sampled populations. Nonetheless, the percentage of highly-annoyed people in the GMC was slightly greater than that in Hong Kong (i.e., 7.9\%).

This research also observed the spatial variability of negative health outcomes at a district level. Seo-gu and Buk-gu were more severely impacted districts than the others, considering the number of people and their geographic distribution with hot spots affected by road traffic noise. In fact, automobile assembly plants and industrial complex are located in Seo-gu and Buk-gu, respectively. This land use pattern of the two districts was speculated to account for a high level of daytime and nighttime road traffic noise, since an industrial area is known to be a major determinant to spatial variation of noise [74]. Higher noise levels due to heavy freight transportation implies an increased percentage of population suffering from high-level psycho-social effects [75].

Previous studies [73] have shown that even though people in residential areas are exposed to the same noise level, annoyance and sleep disturbance may vary depending on their sensitivity. In other words, subjectivity can be involved in \%HA and \%HSD. However, the sensitivity factor was not considered in this study. The \%HA and \%HSD used in this study were derived from meta-analysis using the results of surveys conducted in Europe. Therefore, the \%HA and \%HSD formulas in GMC, ROK may differ from the \%HA and \%HSD formulas suggested by Miedema et al. [7,64]. Thus, it is possible that the results of this study may be revised, depending on the outcome of the questionnaire survey on \%HA and \%HSD of GMC, ROK. This should be considered as a future work, which can also preferably adopt more sophisticated and current road traffic noise models, such as CNOSSOS-EU [76]. 


\section{Conclusions}

This research presented an overview of road traffic noise impacts on inhabitants of the highly-populated Gwangju Metropolitan City in the ROK. Considering the grid noise map, there was no considerable distinctions across the city area between day and night. In addition, the health effect of nighttime road traffic noise could be more severe in the GMC than a highly-urbanized city of both developed and even developing countries, based on the prevalence of \%HSD population estimates. We also noticed that the psychological impacts of road traffic noise were distinct to district levels. That is, the three districts of the city were more impacted by road traffic noise than the other ones, according to the prevalence of $\% \mathrm{HA}$ and \%HSD population estimates.

This study demonstrated that the government of the city urgently needs to take any actions to reduce the psychological impacts of road traffic noise. It is required to enforce a road traffic noise abatement policy to make the nighttime living environment more tranquil at a city level. In addition, as shown in the hot- and cold-spot analysis, the decision makers of the city are recommended to be aware of the importance of the location of the impacted buildings, rather than the impacted districts for such health impact assessment. This is vital in the distribution of available resources to abate road traffic noise levels across the city area.

Although this work is based on an elaborated map of the measured and predicted noise levels, the building-based population data, and the sophisticated hot- and cold-spot analysis, future research that considers the aspects of socioeconomic and environmental inequalities will be important to achieve a more justifiable health impact assessment.

Author Contributions: Formal analysis, T.P., M.K. and C.J.; Investigation, T.C.; Methodology, T.P.; Project administration, S.C.; Resources, K.S. and D.S.; Supervision, S.C.; Writing original draft, T.P.; Writing, review \& editing, M.K. and S.C.

Acknowledgments: This work was supported by the 2015 Research Fund of the University of Seoul for Seo Il Chang. Also, this work was supported by the Basic Science Research Program through the National Research Foundation of Korea (NRF) funded by the Ministry of Education (NRF-2015R1D1A1A01060891) for Taeho Park.

Conflicts of Interest: The authors declare no conflict of interest.

\section{References}

1. Berglund, B.; Lindvall, T.; Schwela, D.H. Guidelines for Community Noise; World Health Organization (WHO): Geneva, Switzerland, 1999. [CrossRef]

2. European Commission. Directive 2002/49/EC of the European Parliament and of the Council of 25 June 2002 Relating to the Assessment and Management of Environmental Noise. Available online: https:/ / publications.europa.eu/en/publication-detail/-/publication/27d1a64e-08f0-4665-a258-9 6f16c7af072/language-en (accessed on 19 August 2018).

3. European Commission Working Group Assessment of Exposure to Noise (WG-AEN). Good Practice Guide for Strategic Noise Mapping and the Production of Associated Data on Noise Exposure Version 2. Available online: https:/ / www.lfu.bayern.de/laerm/eg_umgebungslaermrichtlinie/doc/good_practice_guide_20 07.pdf (accessed on 16 August 2018).

4. King, E.; Murphy, E. Environmental noise-_Forgotten' or 'Ignored' pollutant? Appl. Acoust. 2016, 112, 211-215. [CrossRef]

5. King, E.; Murphy, E.; Rice, H. Implementation of the EU environmental noise directive: Lessons from the first phase of strategic noise mapping and action planning in Ireland. J. Environ. Manag. 2011, 92, 756-764. [CrossRef] [PubMed]

6. EC (European Commission). Report from the Commission to the European Parliament and the Council: On the Implementation of the Environmental Noise Directive in Accordance with Article 11 of Directive 2002/49/EC; European Commission: Brussels, Belgium, 2017.

7. Miedema, H.M.; Oudshoorn, C.G. Annoyance from transportation noise: Relationships with exposure metrics DNL and DENL and their confidence intervals. Environ. Health Perspect. 2001, 109, 409-416. [CrossRef] [PubMed] 
8. Muzet, A. Environmental noise, sleep and health. Sleep Med. Rev. 2007, 11, 135-142. [CrossRef] [PubMed]

9. Perron, S.; Plante, C.; Ragettli, M.S.; Kaiser, D.J.; Goudreau, S.; Smargiassi, A. Sleep disturbance from road traffic, railways, airplanes and from total environmental noise levels in montreal. Int. J. Environ. Res. Public Health 2016, 13, 809. [CrossRef] [PubMed]

10. Babisch, W.; Beule, B.; Schust, M.; Kersten, N.; Ising, H. Traffic noise and risk of myocardial infarction. Epidemiology 2005, 16, 33-40. [CrossRef] [PubMed]

11. Babisch, W.; Swart, W.; Houthuijs, D.; Selander, J.; Bluhm, G.; Pershagen, G.; Dimakopoulou, K.; Haralabidis, A.S.; Katsouyanni, K.; Davou, E.; et al. Exposure modifiers of the relationships of transportation noise with high blood pressure and noise annoyance. J. Acoust. Soc. Am. 2012, 132, 3788-3808. [CrossRef] [PubMed]

12. Dratva, J.; Phuleria, H.C.; Foraster, M.; Gaspoz, J.M.; Keidel, D.; Künzli, N.; Sally Liu, L.J.; Pons, M.; Zemp, E.; Gerbase, M.W.; et al. Transportation noise and blood pressure in a population-based sample of adults. Environ. Health Perspect. 2012, 120, 50-55. [CrossRef] [PubMed]

13. Hammersen, F.; Niemann, H.; Hoebel, J. Environmental noise annoyance and mental health in adults: Findings from the cross-sectional German health update (GEDA) study 2012. Int. J. Environ. Res. Public Health 2016, 13, 954. [CrossRef] [PubMed]

14. Hygge, S.; Evans, G.W.; Bullinger, M. A prospective study of some effects of aircraft noise on cognitive performance in schoolchildren. Psychol. Sci. 2002, 13, 469-474. [CrossRef] [PubMed]

15. Lercher, P.; Evans, G.W.; Meis, M. Ambient noise and cognitive processes among primary schoolchildren. Environ. Behav. 2003, 35, 725-735. [CrossRef]

16. Chetoni, M.; Ascari, E.; Bianco, F.; Fredianelli, L.; Licitra, G. Global noise score indicator for classroom evaluation of acoustic performances in LIFE GIOCONDA project. Noise Mapp. 2016, 3, 157-171. [CrossRef]

17. Murphy, E.; King, E.; Rice, H. Estimating human exposure to transport noise in central Dublin, Ireland. Environ. Int. 2009, 35, 298-302. [CrossRef] [PubMed]

18. Brown, A.L. Effects of road traffic noise on health: From burden of disease to effectiveness of interventions. Procedia Environ. Sci. 2015, 30, 3-9. [CrossRef]

19. D'Alessandro, F.; Schiavoni, S. A review and comparative analysis of European priority indices for noise action plans. Sci. Total Environ. 2015, 518-519, 290-301. [CrossRef] [PubMed]

20. Camusso, C.; Pronello, C. A study of relationships between traffic noise and annoyance for different urban site typologies. Transp. Res. Part D Transp. Environ. 2016, 44, 122-133. [CrossRef]

21. King, R.P.; Davis, J.R. Community noise: Health effects and management. Int. J. Hyg. Environ. Health 2003, 206, 123-131. [CrossRef] [PubMed]

22. Moudon, A.V. Real noise from the urban environment. Am. J. Prev. Med. 2009, 37, 167-171. [CrossRef] [PubMed]

23. Carter, N.L. Transportation noise, sleep, and possible after-effects. Environ. Int. 1996, 22, 105-116. [CrossRef]

24. Pirrera, S.; De Valck, E.; Cluydts, R. Nocturnal road traffic noise: A review on its assessment and consequences on sleep and health. Environ. Int. 2010, 36, 492-498. [CrossRef] [PubMed]

25. Morley, D.W.; De Hoogh, K.; Fecht, D.; Fabbri, F.; Bell, M.; Goodman, P.S.; Elliott, P.; Hodgson, S.; Hansell, A.; Gulliver, J. International scale implementation of the CNOSSOS-EU road traffic noise prediction model for epidemiological studies. Environ. Pollut. 2015, 206, 332-341. [CrossRef] [PubMed]

26. Ruiz-Padillo, A.; Ruiz, D.P.; Torija, A.J.; Ramos-Ridao, Á. Selection of suitable alternatives to reduce the environmental impact of road traffic noise using a fuzzy multi-criteria decision model. Environ. Impact Assess. Rev. 2016, 61, 8-18. [CrossRef]

27. Bunn, F.; Zannin, P.H.T. Assessment of railway noise in an urban setting. Appl. Acoust. 2016, 104, 16-23. [CrossRef]

28. Licitra, G.; Fredianelli, L.; Petri, D.; Vigotti, M.A. Annoyance evaluation due to overall railway noise and vibration in Pisa urban areas. Sci. Total Environ. 2016, 568, 1315-1325. [CrossRef] [PubMed]

29. Iglesias-Merchan, C.; Diaz-Balteiro, L.; Soliño, M. Transportation planning and quiet natural areas preservation: Aircraft overflights noise assessment in a National Park. Transp. Res. Part D Transp. Environ. 2015, 41, 1-12. [CrossRef]

30. Gagliardi, P.; Fredianelli, L.; Simonetti, D.; Licitra, G. ADS-B system as a useful tool for testing and redrawing noise management strategies at Pisa Airport. Acta Acust. Acust. 2017, 103, 543-551. [CrossRef] 
31. Kephalopoulos, S.; Paviotti, M.; Anfosso-Lédée, F.; Van Maercke, D.; Shilton, S.; Jones, N. Advances in the development of common noise assessment methods in Europe: The CNOSSOS-EU framework for strategic environmental noise mapping. Sci. Total Environ. 2014, 482-483, 400-410. [CrossRef] [PubMed]

32. Morel, J.; Marquis-Favre, C.; Gille, L.A. Noise annoyance assessment of various urban road vehicle pass-by noises in isolation and combined with industrial noise: A laboratory study. Appl. Acoust. 2016, 101, 47-57. [CrossRef]

33. Michaud, D.S.; Feder, K.; Keith, S.E.; Voicescu, S.A.; Marro, L.; Than, J.; Guay, M.; Denning, A.; McGuire, D.; Bower, T.; et al. Exposure to wind turbine noise: Perceptual responses and reported health effects. J. Acoust. Soc. Am. 2016, 139, 1443-1454. [CrossRef] [PubMed]

34. Fredianelli, L.; Gallo, P.; Licitra, G.; Carpita, S. Analytical assessment of wind turbine noise impact at receiver by means of residual noise determination without the wind farm shutdown. Noise Control Eng. J. 2017, 65, 417-433. [CrossRef]

35. Doygun, H.; Kusat Gurun, D. Analysing and mapping spatial and temporal dynamics of urban traffic noise pollution: A case study in Kahramanmaras, Turkey. Environ. Monit. Assess. 2008, 142, 65-72. [CrossRef] [PubMed]

36. Gorai, A.; Maity, S.; Pal, A. Development of the path model in road traffic noise annoyance of Dhanbad Township. Noise Vib. Worldw. 2007, 38, 17-22. [CrossRef]

37. Mehdi, M.R.; Kim, M.; Seong, J.C.; Arsalan, M.H. Spatio-temporal patterns of road traffic noise pollution in Karachi, Pakistan. Environ. Int. 2011, 37, 97-104. [CrossRef] [PubMed]

38. Ko, J.H.; Chang, S.I.; Kim, M.; Holt, J.B.; Seong, J.C. Transportation noise and exposed population of an urban area in the Republic of Korea. Environ. Int. 2011, 37, 328-334. [CrossRef] [PubMed]

39. Suárez, E.; Barros, J. Traffic noise mapping of the city of Santiago de Chile. Sci. Total Environ. 2014, 466-467, 539-546. [CrossRef] [PubMed]

40. Chepesiuk, R. Decibel hell: The effects of living in a noisy world. Environ. Health Perspect. 2005, $113,34-41$. [CrossRef]

41. Bluhm, G.L.; Berglind, N.; Nordling, E.; Rosenlund, M. Road traffic noise and hypertension. Occup. Environ. Med. 2007, 64, 122-126. [CrossRef] [PubMed]

42. EEA (Europeon Environment Agency). Road Traffic Remains Biggest Source of Noise Pollution in Europe. Available online: https:/ / www.eea.europa.eu/highlights/road-traffic-remains-biggest-source (accessed on 16 August 2018).

43. Lambert, J.; Simonnet, F.; Vallet, M. Patterns of behaviour in dwellings exposed to road traffic noise. J. Sound Vib. 1984, 92, 159-172. [CrossRef]

44. EPA (Environmental Protection Agency). Our Built and Natural Environments; United States Environmental Protection Agency: Washington, DC, USA, 2001.

45. Klæboe, R.; Amundsen, A.; Fyhri, A.; Solberg, S. Road traffic noise-The relationship between noise exposure and noise annoyance in Norway. Appl. Acoust. 2004, 65, 893-912. [CrossRef]

46. Michaud, D.S.; Keith, S.E.; McMurchy, D. Noise annoyance in Canada. Noise Health 2005, 7, 39-47. [CrossRef] [PubMed]

47. De Kluizenaar, Y.; Janssen, S.A.; van Lenthe, F.J.; Miedema, H.M.E.; Mackenbach, J.P. Long-term road traffic noise exposure is associated with an increase in morning tiredness. J. Acoust. Soc. Am. 2009, 126, 626-633. [CrossRef] [PubMed]

48. Dratva, J.; Zemp, E.; Dietrich, D.F.; Bridevaux, P.O.; Rochat, T.; Schindler, C.; Gerbase, M.W. Impact of road traffic noise annoyance on health-related quality of life: Results from a population-based study. Qual. Life Res. 2010, 19, 37-46. [CrossRef] [PubMed]

49. Ko, J.H.; Chang, S.I.; Lee, B.C. Noise impact assessment by utilizing noise map and GIS: A case study in the city of Chungju, Republic of Korea. Appl. Acoust. 2011, 72, 544-550. [CrossRef]

50. Lee, J.; Gu, J.; Park, H.; Yun, H.; Kim, S.; Lee, W.; Han, J.; Cha, J.S. Estimation of populations exposed to road traffic noise in districts of Seoul metropolitan area of Korea. Int. J. Environ. Res. Public Health 2014, 11, 2729-2740. [CrossRef] [PubMed]

51. KOSIS (Korean Statistical Information Service). Population and Households the 2015 Census; Korean Statistical Information Service: Daejeon, Korea, 2017.

52. GMC (Gwangju Metropolitan City). Gwangju Statistical Yearbook; Gwangju Metropolitan City Office: Gwangju, Korea, 2016. 
53. Hinton, J. How to map noise. Noise Health 2002, 4, 1-5. [PubMed]

54. Abramic, A.; Kotsev, A.; Cetl, V.; Kephalopoulos, S.; Paviotti, M. A spatial data infrastructure for environmental noise data in Europe. Int. J. Environ. Res. Public Health 2017, 14, 726. [CrossRef] [PubMed]

55. Jensen, J.R. Remote Sensing of the Environment: An Earth Resource Perspective, 2nd, ed.; Pearson Prentice Hall: Upper Saddle River, NJ, USA, 2007; pp. 335-408.

56. Barrigón Morillas, J.M.; Montes González, D.; Rey Gozalo, G. A review of the measurement procedure of the ISO 1996 standard. Relationship with the European noise directive. Sci. Total Environ. 2016, 565, 595-606. [CrossRef] [PubMed]

57. Lee, E.Y.; Jerrett, M.; Ross, Z.; Coogan, P.F.; Seto, E.Y. Assessment of traffic-related noise in three cities in the United States. Environ. Res. 2014, 132, 182-189. [CrossRef] [PubMed]

58. SoundPLAN GmbH/SoundPLAN International LLC. SoundPLAN User'S Manual. Available online: https: / / www.google.com/url?sa=t\&rct=j\&q=\&esrc=s\&source=web\&cd=2\&ved=2ahUKEwiI97mxy_rcA hUKdt4KHbSkCp4QFjABegQICRAC\&url=https\%3A\%2F\%2Fwww.aacacustica.com\%2Fgaleria\%2FUpda te_8.0_EN.pdf\&usg=AOvVaw0S7sJjNFXWif--o_vM8vmw (accessed on 16 August 2018).

59. Forschungsresellschaft für Straßen-und Verkehrswesen. Richtlinien für den Lärmschutz an Straßen: RLS-90; Verkehrsblatt: Köln, Germany, 1990.

60. Sétra. Road Noise Prediction-Part 2: Noise Propagation Computation Method Including Meteorological Effects (NMPB 2008). Available online: https://www.researchgate.net/publication/263920715_Road_noise_ prediction_2_-_Noise_propagation_computation_method_inclu_ding_meteorological_effects_NMPB_200 8 (accessed on 16 August 2018).

61. Department of Transport Welsh Office. Calculation of Road Traffic Noise. Available online: https: / / www.google.com/url?sa=t\&rct=j\&q=\&esrc=s\&source=web\&cd=1\&ved=2ahUKEwjr7bTZy_r cAhVJ_GEKHTkhCQUQFjAAegQIChAC\&url=http\%3A\%2F\%2Fwww.devon.gov.uk\%2Fcore-doc-n3-calcul ation-of-road-traffic-noise.pdf\&usg=AOvVaw3KTbBhmY0jMPM91D-XZ1Rw (accessed on 16 August 2018).

62. Tachibana, H. Road traffic noise prediction model ASJ RTN Model 2003. J. Acoust. Soc. Jpn. 2004, 60, $192-241$.

63. Jonasson, H.G.; Storeheier, S. Nord 2000. New Nordic Prediction Method for Rail Traffic Noise; SP Swedish National Testing and Research Institute: Borås, Sweden, 2001.

64. Miedema, H.M.E.; Passchier-Vermeer, W.; Vos, H.; Delft, C. Elements for a Position Paper on Night-Time Transportation Noise and Sleep-Disturbance; TNO: Delft, The Netherland, 2002.

65. World Health Organization Regional Office for Europe. Burden of Disease from Environmental Noise. Available online: https:/ / www.google.com/url?sa=t\&rct=j\&q=\&esrc=s\&source=web\&cd=1\&ved=2ahU KEwjRuPL3y_rcAhVBWEKHd7eBBIQFjAAegQICBAC\&url=http\%3A\%2F\%2Fwww.euro.who.int\%2F_d ata\%2Fassets\%2Fpdf_file\%2F0008\%2F136466\%2Fe94888.pdf\&usg=AOvVaw0mMOD7Y1G0R9BiJjyDBcJ5 (accessed on 16 August 2018).

66. Kim, M.; Chang, S.I.; Seong, J.C.; Holt, J.B.; Park, T.H.; Ko, J.H.; Croft, J.B. Road traffic noise: annoyance, sleep disturbance, and public health implications. Am. J. Prev. Med. 2012, 43, 353-360. [CrossRef] [PubMed]

67. Basner, M.; Babisch, W.; Davis, A.; Brink, M.; Clark, C.; Janssen, S.; Stansfeld, S. Auditory and non-auditory effects of noise on health. Lancet (Lond. Engl.) 2014, 383, 1325-1332. [CrossRef]

68. Houthuijs, D.J.M.; van Beek, A.J.; Swart, W.J.R.; van Kempen, E.E.M.M. Health Implication of Road, Railway and Aircraft Noise in the European Union: Provisional Results Based on the 2nd Round of Noise Mapping; National Institute for Public Health and the Environment: Bilthoven, The Netherlands, 2014.

69. Rey Gozalo G, B.M.J. Analysis of sampling methodologies for noise pollution assessment and the impact on the population. Int. J. Environ. Res. Public Health 2016, 13, 490. [CrossRef] [PubMed]

70. Zytoon, M.A. Opportunities for environmental noise mapping in Saudi Arabia: A case of traffic noise annoyance in an urban area in Jeddah City. Int. J. Environ. Res. Public Health 2016, 13, 496. [CrossRef] [PubMed]

71. Allen, D.W. GIS Tutorial 2: Spatial Analysis Workbook; Esri Press: Redlands, CA, USA, 2013; p. 329.

72. Ryu, H.; Park, I.K.; Chun, B.S.; Chang, S.I. Spatial statistical analysis of the effects of urban form indicators on road-traffic noise exposure of a city in South Korea. Appl. Acoust. 2017, 115, 93-100. [CrossRef]

73. Brown, A.L.; Lam, K.C.; van Kamp, I. Quantification of the exposure and effects of road traffic noise in a dense Asian city: A comparison with western cities. Environ. Health 2015, 14, 22. [CrossRef] [PubMed] 
74. Zuo, F.; Li, Y.; Johnson, S.; Johnson, J.; Varughese, S.; Copes, R.; Liu, F.; Wu, H.J.; Hou, R.; Chen, H. Temporal and spatial variability of traffic-related noise in the City of Toronto, Canada. Sci. Total Environ. 2014, 472, 1100-1107. [CrossRef] [PubMed]

75. Ali, S.A. Investigation of the dose-response relationship for road traffic noise in Assiut, Egypt. Appl. Acoust. 2004, 65, 1113-1120. [CrossRef]

76. Kephalopoulos, S.; Paviotti, M.; Anfosso-Lédée, F. Common Noise Assessment Methods in Europe (CNOSSOS-EU); Publications Office of the European Union: Luxembourg, 2012; ISSN 1831-9424.

(C) 2018 by the authors. Licensee MDPI, Basel, Switzerland. This article is an open access article distributed under the terms and conditions of the Creative Commons Attribution (CC BY) license (http:/ / creativecommons.org/licenses/by/4.0/). 